\title{
PENGUKURAN PSNR PADA TRANSMISI VIDEO DI KANAL TERAHERTZ MENGGUNAKAN QAM MODULATION
}

\author{
${ }^{1}$ Tamara Maharani, ${ }^{2}$ Muhammad Agus Zainuddin, ${ }^{2}$ Sritrusta Sukaridhoto \\ ${ }^{1}$ Akademi Komunitas Negeri Pacitan, ${ }^{2}$ Politeknik Elektronika Negeri Surabaya \\ 1 Jl. Walanda Maramis No 4A Pacitan, 0357-881657 / 0357-881652 \\ 2 Jl. Raya ITS Sukolilo - Surabaya, 031-5947280/ 031-5946114 \\ tamara@aknpacitan.ac.id, magusz@pens.ac.id, dhoto@pens.ac.id
}

\begin{abstract}
In the current era of communication has various challenges that include the intensity of information exchange more often, the amount of information carried and the speed in exchanging information. Communication is not only in the form of text and sound but also in the form of pictures and videos. This study tries to use digital data in the form of video with the aim of providing a view of the PSNR measurement simulation. The method used is modulation of QAM 64, 256, 1024 and 4096 through terahertz channels (0.1-10 THz). Simulation results show that in QAM 64 the PSNR value is $35.2 \mathrm{~dB}$ to $36.6 \mathrm{~dB}$. The PSNR value decreases as the M-ary increases. PSNR at 256 QAM ranges from 25.9 to $26.5 \mathrm{~dB}$. PSNR in QAM 1024 is stable at magnitude 16.3 to 16.5. Whereas PSNR in QAM 4096 ranged from 15.0 to 15.25. From this study shows the greater the value of PSNR, the quality of information sent is increasingly similar. In addition, the higher the M-ary, the data carried will also be large so as to speed up the transmission time.
\end{abstract}

Keywords: Terahertz, QAM, PSNR, Video, Simulation

\begin{abstract}
Abstrak
Di era saat ini komunikasi memiliki berbagai tantangan yang meliputi intesitas pertukaran informasi yang lebih sering, besarnya informasi yang dibawa dan kecepatan dalam bertukar informasi. Komunikasi tidak hanya berupa text dan suara namun juga berupa gambar dan video. Penelitian ini mencoba menggunakan data digital berupa video dengan tujuan memberikan pandangan tentang simulasi pengukuran PSNR. Metode digunakan yaitu modulasi QAM 64, 256, 1024 dan 4096 melalui kanal terahertz (0.1-10 THz). Hasil simulasi menunjukkan pada QAM 64 nilai PSNR sebesar 35.2 dB hingga $36.6 \mathrm{~dB}$. Nilai PSNR menurun seiring bertambahnya M-ary. PSNR pada QAM 256 di rentang 25.9 hingga 26.5 dB. PSNR pada QAM 1024 stabil di besaran 16.3 sampai 16.5. Sedangkan PSNR pada QAM 4096 di rentang 15.0 hingga 15.25. Dari penelitian ini menunjukkan semakin besar nilai PSNR maka kualitas informasi yang dikirimkan semakin mirip. Selain itu semakin tinggi M-ary maka data yang dibawa pun juga ikut besar sehingga mempercepat waktu transimisi.
\end{abstract}

Kata kunci: Terahertz, QAM,PSNR, Video, Simulasi 


\section{PENDAHULUAN}

Seiring berjalannya waktu, komunikasi di era saat ini tidak hanya bertukar text dan suara, tetapi juga bertukar gambar dan video dengan data yang besar dan kebutuhan pertukarannya juga lebih sering. Oleh sebab itu diperlukan layanan komunikasi nirkabel dalam hal kecepatan transmisi, keandalan komunikasi, jumlah layanan, dan lain-lain.

Alasan yang mendasar mengapa saat ini di bidang komunikasi banyak melakukan penelitian tentang terahertz karena kanal terahertz menjanjikan kecepatan super-broadband atau kecepatan data tinggi yang dua kali lipat dari kecepatan saat ini [1]. Penelitian lain yang terkait komunikasi terahertz dilakukan oleh Josep Miquel Jornet dkk yang menggunakan frekuensi $0.1 \mathrm{THz}-10 \mathrm{THz}$ dengan menguji kecanggihan perangkat $\mathrm{THz}$ terutama dari kecepatan data dan menyoroti potensinya 5 sampai 10 tahun yang akan datang [2]. Komunikasi pada pita Terahertz memiliki bandwidth yang sangat besar, sehingga mendukung laju transmisi data sampai dengan beberapa Tbps [3].

Pada Gambar 1 adalah perbandingan frekuensi dan pencapaian laju data, tampak bahwa semakin tinggi frekuensi kerja, laju transmisi yang dapat diperoleh semakin meningkat dan di masa depan perkembangan laju transmisi juga diperkirakan mengalami kenaikan sangat pesat seiring dengan kemajuan teknologi. Karena hal tersebut banyak peneliti saat ini yang mengembangkan penelitian di saluran terahertz $(0.1-10 \mathrm{THz})$.

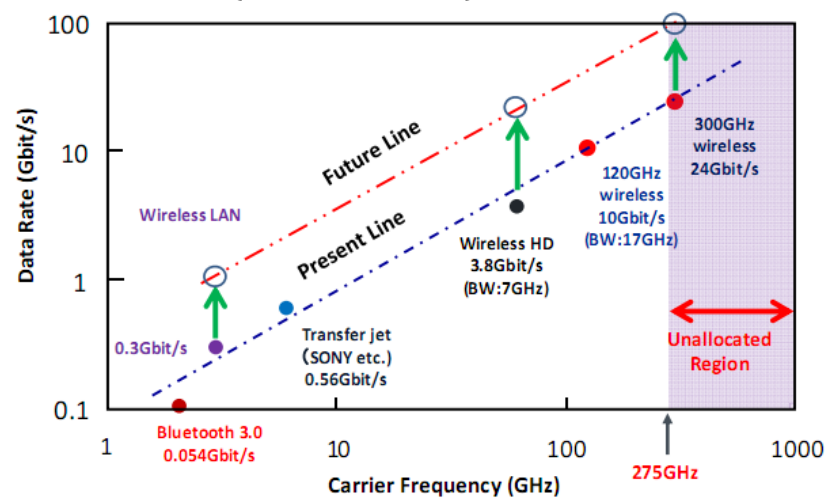

Gambar 1. Performa Laju Data

Gelombang Terahertz (THz) adalah bagian dari spektrum elektromagnetik yang memiliki panjang gelombang antara infra merah dan gelombang mikro. Frekuensi terahertz berada di celah antara frekuensi elektronik dan fotonik [4].

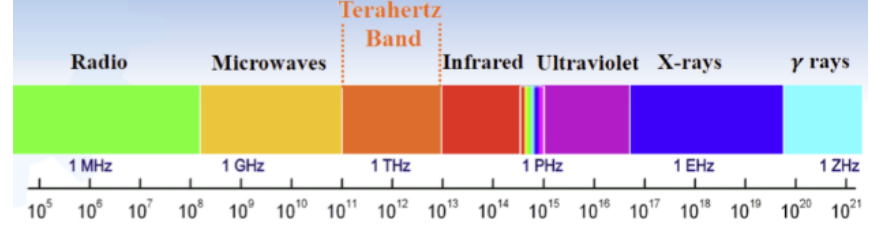

Gambar 2. Cakupan Frekuensi Terahertz [5]

Pada Gambar 2 diatas merupakan rentang pita frekuensi terahertz yang dibedakan menurut warna. Karena mengacu pada minat dan kontribusi peneliti 
yang berbeda-beda maka cakupan frekuensi terahertz digolongkan menjadi 3 aspek sebagai dasar acuan para peneliti seperti yang dijelaskan pada Tabel 1.

\begin{tabular}{|c|c|c|}
\hline & $\begin{array}{l}\text { Cakupan } \\
\text { Frekuensi }\end{array}$ & $\begin{array}{l}\text { Panjang } \\
\text { Gelombang }\end{array}$ \\
\hline $\begin{array}{ll}\text { Industri, } & \text { IEEE } \\
802.15 .3 d & \end{array}$ & $0.3 \mathrm{THz}-3 \mathrm{THz}$ & $1 \mathrm{~mm}-3 \mu \mathrm{m}$ \\
\hline $\begin{array}{l}\text { Academia } \\
\text { Smart Academia }\end{array}$ & $\begin{array}{l}0.1 \mathrm{THz}-10 \mathrm{THz} \\
0.06 \mathrm{THz}-10 \mathrm{THz}\end{array}$ & $\begin{array}{l}3 m m-30 \mu m \\
5 m m-3 \mu m\end{array}$ \\
\hline
\end{tabular}

\subsection{Noise Terahertz}

Dalam pentransmisian tidak lepas dari adanya noise. Derau atau yang biasa disebut noise adalah suatu sinyal gangguan yang bersifat akustik, elektris, maupun elektronis yang hadir dalam suatu sistem rangkaian listrik/ elektronika dalam bentuk gangguan yang bukan merupakan sinyal yang diinginkan [7]. Pada kanal terahertz, terdapat noise yang disebut molecular arbsoption noise yang tidak hanya menyerap gelombang magnetik tetapi juga meradiasikan kembali gelombang pada frekuensi yang sama dengan gelombang datang [8]. Arbsorpsi noise sebagaimana pada persamaan 1 .

$$
\varepsilon(f, d)=1-\tau(f, d)
$$

Sedangkan temperatur noise dapat diperoleh sebagaimana pada persamaan 2 .

$$
T_{\text {mol }}(f, d)=T_{0} \varepsilon(f, d)
$$

Dimana $\mathrm{T}_{0}$ adalah referensi temperatur.

Untuk molecular noise arbsoption dapat dikomputasikan sebagaimana persamaan 3.

$$
P_{n}(f, d)=\int_{B} k_{B} T_{0} \varepsilon(f, d) d f
$$

Dimana $B$ adalah bandwidth dan $k_{B}$ adalah kontanta Boltzmann.

\subsection{Kualitas Video}

Sinyal multimedia memiliki ukuran data yang besar, sehingga dibutuhkan teknik kompresi apabila akan ditransmisikan [9]. Laju data berkaitan erat dengan pemakaian dan pemilihan codec (metode kompresi video). Beberapa codec menghendaki laju data tertentu, misalnya MPEG-2 yang digunakan dalam format DVD memiliki bit rate $9800 \mathrm{kbps}$ atau 9,8 Mbps (maksimal), sedangkan VCD maksimal bit rate sebesar 1,15 Mbps [10].

Kecepatan pengiriman video rata-rata 30 fps. Pengiriman video tanpa proses kompresi, membutuhkan bandwidth kurang lebih sebesar 9 Mbps [11]. Pada Tabel 2 hubungan rasio kompresi dengan PSNR dan bitrate. 
Tabel 2. Kompresi Video [12]

\begin{tabular}{llll}
\hline & $\begin{array}{l}\text { Rata-rata } \\
\text { PSNR (dB) }\end{array}$ & $\begin{array}{l}\text { Bitrate } \\
\text { (Kbit/s) }\end{array}$ & Rasio Kompresi \\
\hline Original 30 fps & - & 9124 & $1: 1$ \\
$10 \mathrm{fps}, 20 \mathrm{Kbps}$ & 38.51 & 22.81 & $133: 1$ \\
$10 \mathrm{fps}$, 50 Kbps & 41.75 & 56.70 & $54: 1$ \\
$10 \mathrm{fps}, 100 \mathrm{Kbps}$ & 43.98 & 112.09 & $27: 1$ \\
$10 \mathrm{fps}, 500 \mathrm{Kbps}$ & 48.38 & 505.61 & $6: 1$ \\
\hline
\end{tabular}

Terkait kompresi yang dipaparkan pada Tabel 2, penelitian terkait juga dilakukan oleh Muhammad Agus Zainuddin, Eugen Dedu, dan Julien Bourgeois melalukan riset tentang Simple and Energy Efficient Image Compression (SEIC) for pulse-based communication in $\mathrm{THz}$ band [13] dengan membahas kompresi citra terahertz yang dapat digunakan dalam skala makro maupun skala mikro. Kompresi didasarkan pada Discreate Wavelet Transform (DWT) dengan kode berbobot rendah (low weight code). Hasil penelitian berupa simulasi yang menunjukkan bahwa metode yang digunakan memperoleh efisiensi energi sebesar 88\% mengungguli JPEG, JPEG 2000, GIF dan PNG dalam hal efisiensi serta ketahanan terhadap kesalahan transmisi.

\subsection{PSNR (Peak Signal to Noise Ratio)}

Dalam Tabel 2 terdapat rata-rata PSNR pada tiap-tiap urutan frame video. PSNR adalah suatu besaran yang merupakan perbandingan antara kekuatan sinyal maksimum dengan kekuatan noise [14]. Secara umum, sinyal memilki rentang nilai yang cukup luas, sehingga untuk mempermudah PSNR ditulis dalam satuan decibel (dB). Cara menghitung PSNR dengan menentukan terlebih dahulu nilai Mean Square Error (MSE) dan Root Mean Square Error (RMSE) seperti yang dituliskan pada persamaan 4 dan persamaan 5 .

$$
\begin{aligned}
M S E & =\frac{1}{m \times n} \sum_{i=0}^{n-1} \sum_{j=0}^{m-1}[f(i, j)-g(i, j)]^{2} \\
R M S E & =\sqrt{\frac{1}{m \times n} \sum_{i=0}^{n-1} \sum_{j=0}^{m-1}[f(i, j)-g(i, j)]^{2}}
\end{aligned}
$$

Sesuai perhitungan pada persamaan 4 dan 5 maka nilai citra akan mendekati nol apabila terjadi kemiripan[15].

$$
P S N R=10 \log _{10} \frac{255^{2}}{M S E}
$$

Melihat persamaan 6, nilai PSNR dibawah $30 \mathrm{~dB}$ jika jika terdapat kemiripan yang rendah pada dua buah citra [16].

Berdasarkan pemaparan tersebut maka diperlukan sebuah model simulasi yang dapat menggambarkan sistem komunikasi terahertz. Penelitian yang kami lakukan berfokus pada simulasi dengan pengukuran berupa PSNR menggunakan 
modulasi QAM 64, 256, 1024 dan 4096 yang menggunakan data input berupa video.

\section{METODOLOGI PENELITIAN}

Dengan adanya model simulasi ini, diharapkan memperoleh hasil simulasi terbaik pada saluran komunikasi terahertz. Pada bab ini akan dijelaskan bagaimana alur penelitian yang dilakukan antara lain :

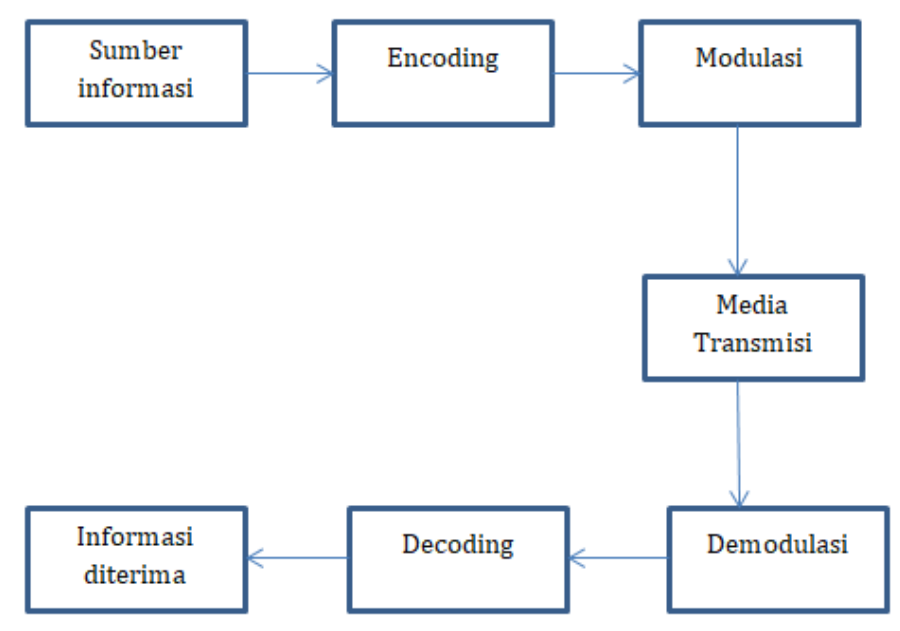

Gambar 3. Blok Diagram Sistem

\subsection{Sumber Informasi}

Sumber informasi yang digunakan dalam pengujian ini berupa video xylophone.mpg. Simulasi ini menggunakan software Matlab R2018a. Tangkapan layar video diperlihatkan pada Gambar 4.

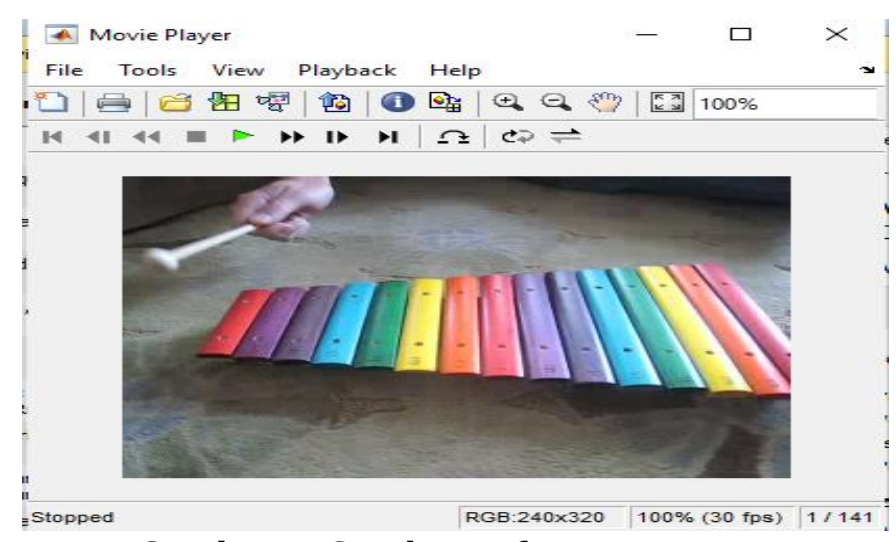

Gambar 4. Sumber Informasi

\section{$2.2 \quad$ Modulasi}

Setelah melalui tahapan encoding, sebelum ditransmisikan, sinyal memerlukan proses modulasi terlebih dahulu. Modulasi adalah penumpangan sinyal informasi pada sinyal pembawa dengan cara mengubah amplitude, frekuensi atau fase dari sinyal pembawa [17] tergantung dari jenis modulasi yang 
dipilih. Penulis disini menggunakan modulasi QAM dengan pertimbangan modulasi QAM merupakan gabungan dari modulasi ASK dan PSK yang mampu menawarkan kecepatan yang lebih tinggi karena setiap simbol yang ditransmisikan membawa beberapa bit informasi sekaligus.

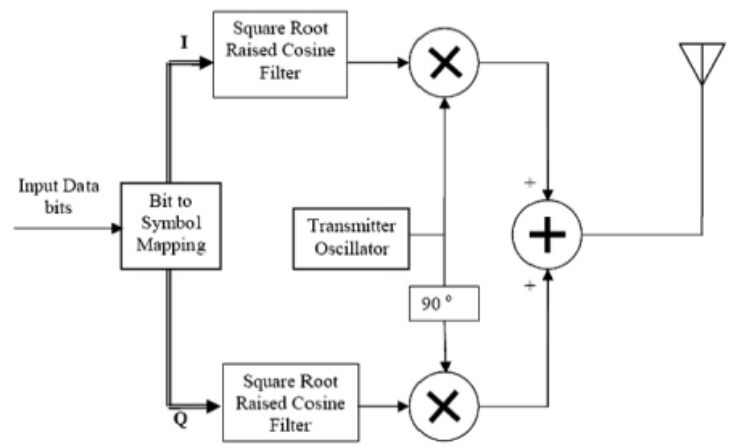

Gambar 5. Skema Modulasi QAM

Pada skema modulasi M-QAM pada Gambar 5, QAM membagi sinyal yang ditransmisikan menjadi dua bagian, dimana kedua bagian berbeda dalam fase $90^{\circ}$. Pertama data input dikelompokkan dengan Gray Mapping (Gray Coding) ke dalam koordinat konstelasi sinyal biner In-phase (I) dan Quadrature (Q) [18] seperti Gambar 5. $M$ adalah jumlah multilevel modulasi atau jumlah maksimum data pada M-QAM dalam bentuk bit. Contoh untuk sistem 64 QAM dapat dikirimkan 64 data dalam biner. Jumlah untaian biner yang dapat mempresentasikan data disebut dengan ukuran konstelasi bit, disimbolkan dengan $k$, dan dapat dinyatakan sebagai

$$
k=\log _{2} M
$$

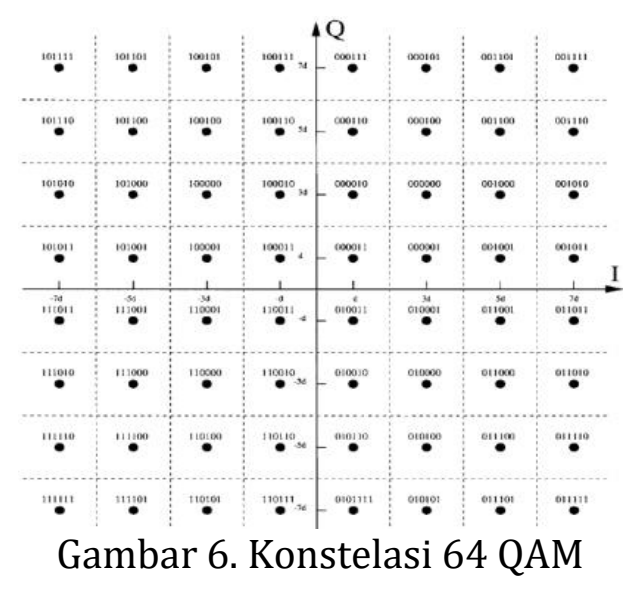

Pada Gambar 6 merupakan contoh dari diagram konstelasi 64 QAM. Konstelasi adalah pola modulasi digital pada bidang kompleks dan diurutkan berdasarkan aturan kode gray [19]. Kode Gray merupakan pengurutan nilai biner dimana kedua nilai yang berdekatan hanya mempunyai perbedaan satu digit. 
Manfaat kode gray yaitu mengurangi bit error yang terjadi. Jumlah titik-titik pada diagram berupa pemangkatan dari $2^{n}$, sebab pada komunikasi digital, informasi yang diolah berupa nilai biner.

\subsection{Demodulasi}

Kebalikan dari modulasi. Demodulasi berada pada sisi penerima. Demodulator bertugas menerima sinyal dan memisahkan antara sinyal pembawa dengan sinyal informasi. Karena sinyal yang diterima juga membawa noise yang disebabkan oleh jarak tempuh, cuaca, dan lain-lain.

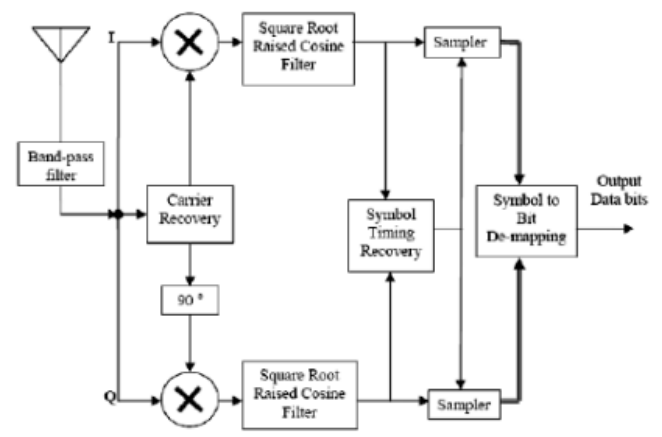

Gambar 7. Skema Demodulasi QAM

Pada Gambar 6, karena demodulasi merupakan proses kebalikan dari modulasi maka aliran sinyal-sinyal analog akhirnya dikembalikan menjadi sinyalsinyal biner dengan menggunakan Gray Mapping.

\section{HASIL DAN PEMBAHASAN}

Pada bab ini menjelaskan mengenai pengukuran PSNR pada kanal terahertz dengan input video xylophone.mpg menggunakan modulasi dan demodulasi QAM 64, 256, 1024 dan 4096.
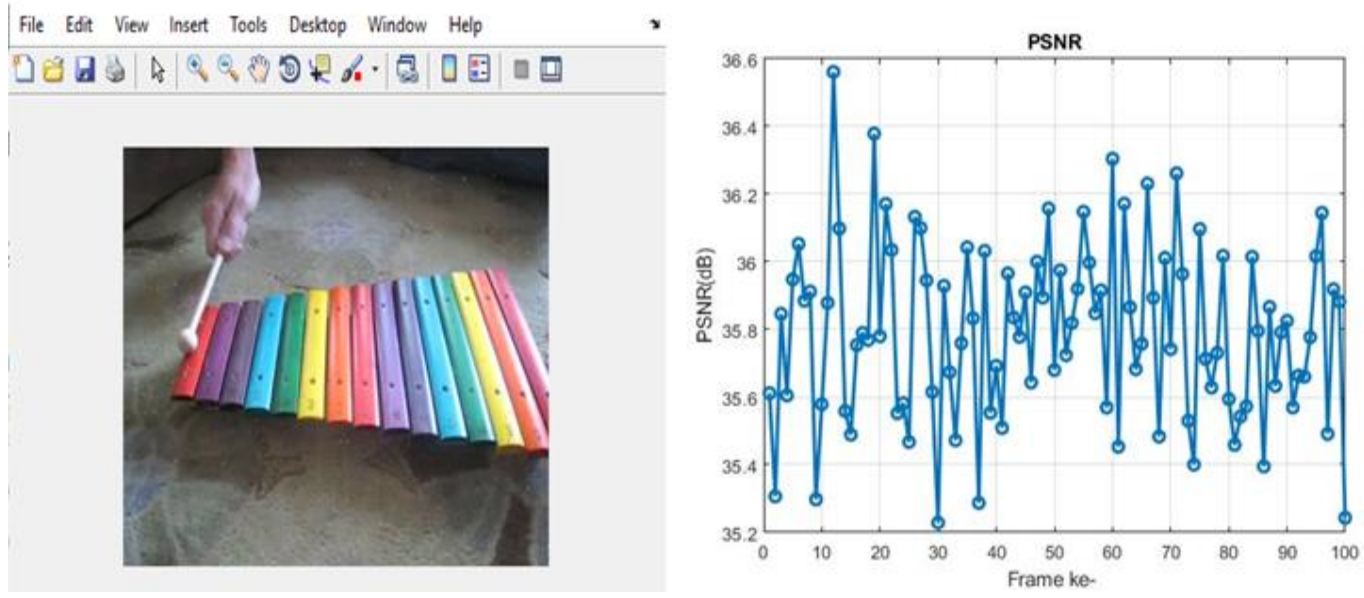

Gambar 8. Hasil Video Transmisi dan PSNR Menggunakan 64 QAM 
Pada Gambar 8, merupakan pengukuran menggunakan QAM 64. Hasil video masih terbilang jernih karena belum banyak terkontaminasi noise. Hasil pengukuran PSNR terlihat nilai puncak PNSR cukup tinggi direntang $35.2 \mathrm{~dB}$ hingga $36.6 \mathrm{~dB}$. Terjadi kenaikan dB yang cukup signifikan mulai dari frame ke 12 .
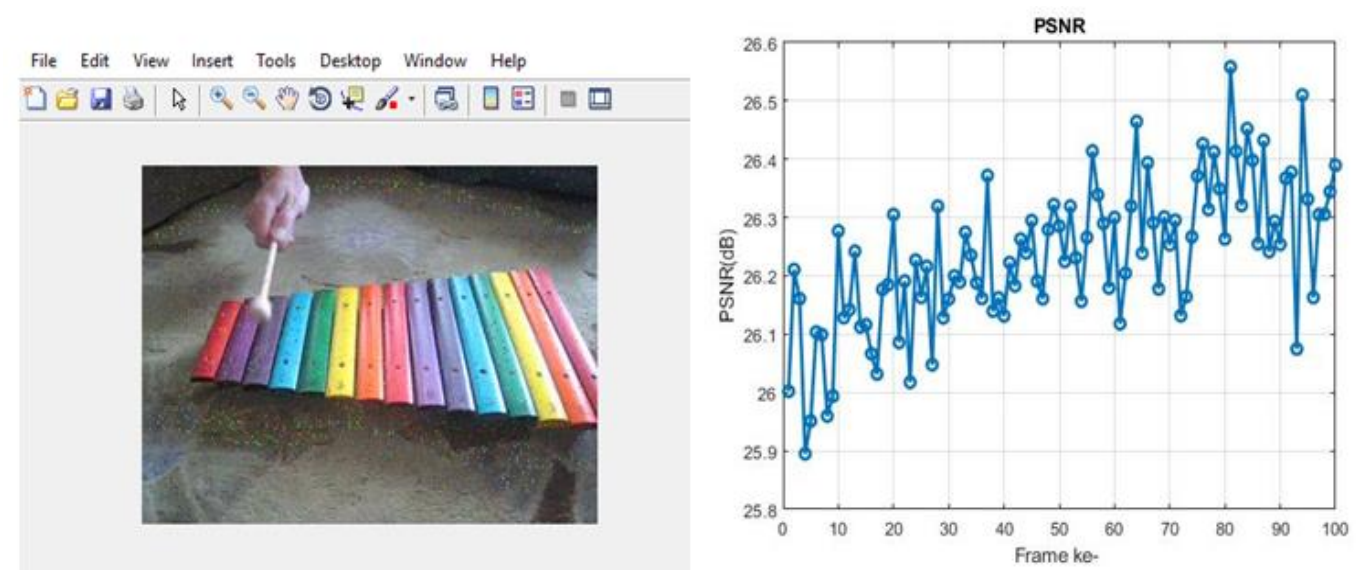

Gambar 9. Hasil Video Transmisi dan PSNR Menggunakan 256 QAM

Pada Gambar 9, merupakan pengukuran menggunakan QAM 256. Hasil video masih terbilang jernih namun sedikit lebih banyak terkontaminasi noise dibanding QAM 64. PSNR sedikit menurun di rentang 25.9 hingga 26.5. Kenaikan PSNR yang cukup tinggi berada di frame 80 sedangkan terendah di frame ketiga.
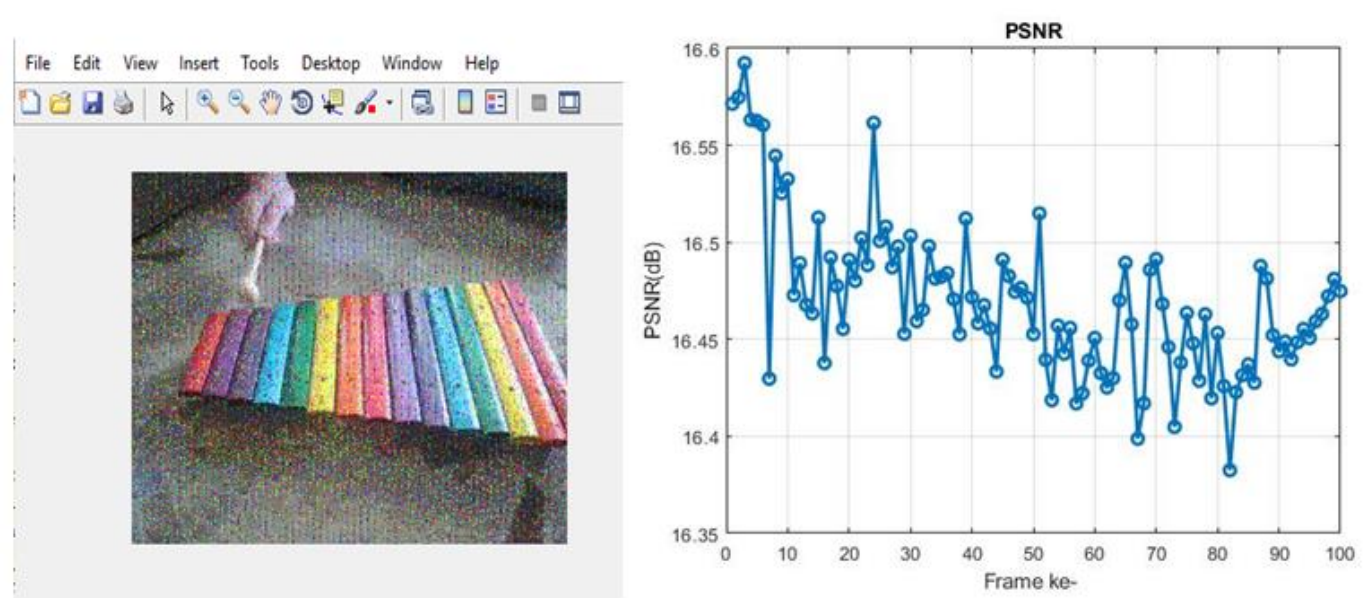

Gambar 10. Hasil Video Transmisi dan PSNR Menggunakan 1024 QAM

Pada Gambar 10, merupakan pengukuran menggunakan QAM 1024. Hasil transmisi video cukup banyak terlihat gangguan noise tetapi masih jelas meskipun tidak jernih. Pengukuran PSNR di frekuensi terahertz stabil di angka $16.3 \mathrm{~dB}$ hingga $16.5 \mathrm{~dB}$. 

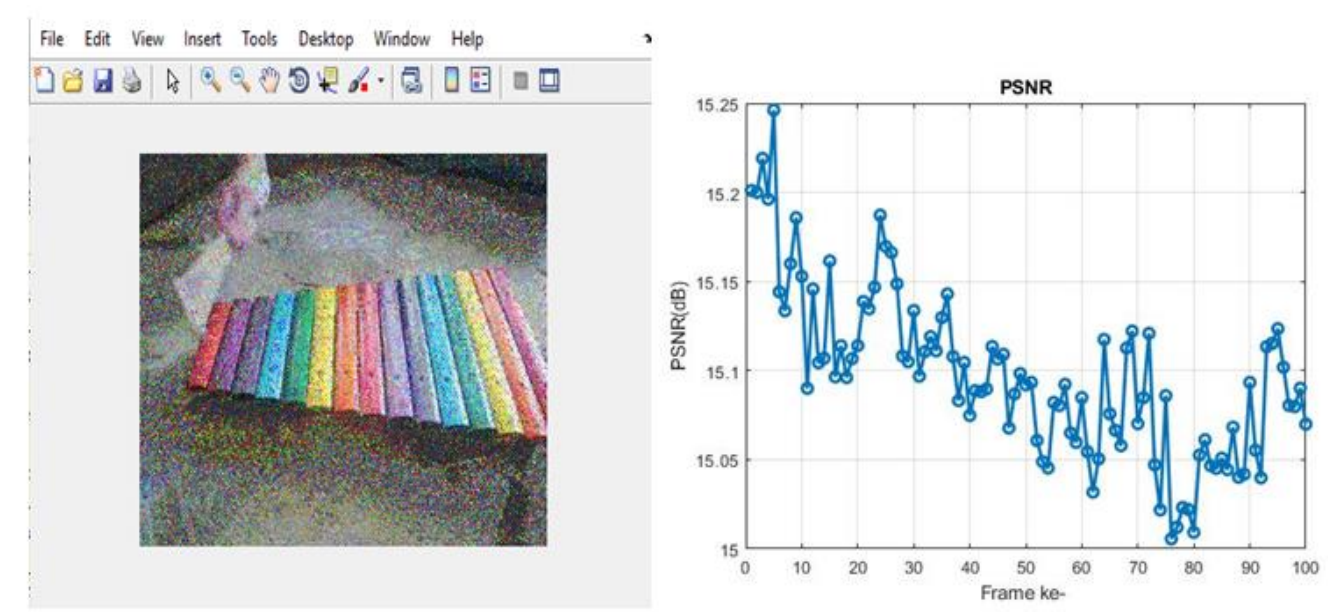

Gambar 11. Hasil Video Transmisi dan PSNR Menggunakan 4096 QAM

Jika menggunakan QAM 4096, pada Gambar 11 terlihat hasil dari transmisi video sudah banyak mengalami gangguan namun masih terbaca. Nilai PSNR untuk transmisi video stabil mengalami penurunan 1 angka dibandingkan dengan QAM 1024. PSNR QAM 4096 berada di kisaran 15 hingga $15.25 \mathrm{~dB}$.

\section{SIMPULAN}

Berdasarkan percobaan menggunakan video xylophone.mpg pada kanal terahertz, maka dapat disimpulkan :

a. Semakin besar nilai M-ary, maka nilai PSNR (dB) semakin kecil.

b. Semakin kecil nilai M-ary, noise yang dibawa juga kecil.

c. Semakin besar nilai M-ary, maka bit-bit yang diwakilkan dalam 1 simbol juga semakin besar, gangguan juga semakin besar.

d. Semakin besar PSNR maka kualitas kompresi mendekati citra atau informasi aslinya.

\section{DAFTAR PUSTAKA}

[1] F. Fesharaki, T. Djerafi, M. Chaker, and K. Wu, "Mode-selective transmission line for DC-to-THz super-broadband operation," IEEE MTT-S Int. Microw. Symp. Dig., vol. 2016-Augus, no. 1, pp. 10-13, 2016, doi: 10.1109/MWSYM.2016.7540187.

[2] C. Akyildiz, Ian \& Jornet, Josep \& Han, "TeraNets: Ultra-broadband communication networks in the terahertz band."

[3] I. F. Akyildiz, J. M. Jornet, and C. Han, "Terahertz band: Next frontier for wireless communications," Phys. Commun., vol. 12, pp. 16-32, 2014, doi: 10.1016/j.phycom.2014.01.006.

[4] U. S. Utara, Terahertz. .

[5] M. Huda, "Teknologi Terahertz, Penuh Dengan Harapan dan Tantangan." https://stunecity.wordpress.com/2008/05/18/teknologi-terahertz-penuhdengan-harapan-dan-tantangan/.

[6] V. Petrov, "THz Channel Properties." 
[7] Wikipedia,

"Derau." https://id.wikipedia.org/w/index.php?title=Derau\&stable=1.

[8] J. Kokkoniemi, J. Lehtomäki, and M. Juntti, "A discussion on molecular absorption noise in the terahertz band," Nano Commun. Netw., vol. 8, pp. 3545, 2015, doi: 10.1016/j.nancom.2015.11.001.

[9] D. W. and D. Y. J. Tian, H. Zhang, "Interference-Aware Cross-Layer Design for Distributed Video Transmission in Wireless Networks."

[10] M. Haykal, "Analisis Perbandingan Efesiensi dan Efektifitas Antara Codec H.264 dan VP7 Pada Sistem Video Conference," pp. 1-90, 2011, [Online]. Available: http://repository.uinjkt.ac.id/dspace/handle/123456789/21432.

[11] A. I. Diwi, R. R. Mangkudjaja, and I. Wahidah, "Analisis Kualitas Layanan Video Live Streaming pada Jaringan Lokal Universitas Telkom," Bul. Pos dan Telekomun., vol. 12, no. 3, p. 207, 2015, doi: 10.17933/bpostel.2014.120304.

[12] S. Sudiarjo, "UNIVERSITAS INDONESIA PENGUKURAN PARAMETER KUALITAS LAYANAN (QoS) TRAFIK," Skripsi, p. 80, 2010.

[13] M. A. Zainuddin, E. Dedu, and J. Bourgeois, "Simple and energy efficient image compression for pulse-based communication in thz band," Proc. - Int. Conf. Adv. Inf. Netw. Appl. AINA, pp. 112-119, 2017, doi: 10.1109/AINA.2017.109.

[14] S. Siregar, "Menghitung Peak signal-to-noise ratio (PSNR) dengan menggunakan python dan scikit-image." https://radiokuantum.wordpress.com/2017/07/13/menghitung-peaksignal-to-noise-ratio-psnr-dengan-menggunakan-python-dan-scikitimage/\#: :text=PSNR adalah suatu besaran yang,dalam satuan decibel $(\mathrm{dB})$.

[15] A. M. Faza, C. Slamet, and D. Nursantika, "Analisis Kinerja Kompresi Citra Digital dengan Komparasi DWT, DCT dan Hybrid (DWT-DCT)," J. Online Inform., vol. 1, no. 1, p. 1, 2016, doi: 10.15575/join.v1i1.3.

[16] F. Nurul Hikmah, "Penerapan Fade Untuk Mengukur Citra Pasca Proses Haze Removal ( Studi Kasus Citra Berkabut Pada Kawah Gunung Kelud )," 2017.

[17] C. E. B. University, "Teknik Quadrature Amplitude Modulation untuk Pegiriman Data Melalui Frekuensi Voice Band." https://compeng.binus.ac.id/files/2014/05/TEKNIK-QUADRATURE-AMPLITUDEMODULATION-QAM-UNTUK-PENGIRIMAN-DATA-MELALUI-FREKUENSIVOICE-BAND-.pdf.

[18] M. M. M. Wireless and F. A. Marpalinda, "Implementasi dan evaluasi kinerja sistem komunikasi," 2015.

[19] A. Y. Prasetya and T. Suryani, "Implementasi Modulasi dan Demodulasi Mary QAM pada DSK TMS320C6416T," Implementasi Modul. dan Demodulasi M-ary QAM pada DSK TMS320C6416T, vol. 1, no. 1, pp. 1-6, 2013. 